Acta vet. scand. $1967,8,136-149$.

From the Department of Physiology, Veterinary College of Norway, Oslo.

\title{
THE IN VITRO CATABOLISM OF HISTAMINE IN TISSUES OF THE DIGESTIVE TRACT IN SHEEP*)
}

By

Ø. V. Sjaastad

After feeding silage, high concentrations of histamine were usually found in the rumen of sheep (Sjaastad $1967 \mathrm{a}$ ). The biological activity of histamine disappeared much faster from the rumen than did polyethylene glycol (PEG), a substance which is neither absorbed by the rumen epithelium nor destroyed by the ruminal microflora (Sperber et al. 1953). However, the experimental data gave no clear answer as to whether the faster disappearance of histamine than of the inert marker was mainly due to absorption of free histamine by the rumen epithelium or inactivation of histamine by rumen bacteria (Sjaastad 1967 a).

After giving histamine by mouth, high biological activity was also found in the abomasum (Sjaastad 1967a). Further, histamine is rapidly absorbed as such from jejunal loops of sheep (Sjaastad $\&$ Kay, unpublished). This indicates that some of the histamine ingested with the food is absorbed unchanged from the small intestines.

When silage rich in histamine was fed, the increments in urinary free histamine were minimal and no signs of intoxication were observed (Sjaastad $1967 \mathrm{~b}, \mathrm{c}$ ). On the other hand, when histamine is administered parenterally to sheep, $2-4 \%$ of the administered dose is recovered as biological activity in the urine and even small amounts administered in this way also cause signs of intoxication (Dougherty 1942; Sjaastad, unpublished).

*) This work was financially supported by the Agricultural Research Council of Norway. The author is indebted to Miss Liv Burum and Mrs. Solvaar Eliassen for technical assistance. 
The above mentioned observations indicated that histamine, if absorbed as such in considerable amounts from the digestive tract, must be efficiently inactivated before reaching the systemic circulation. The possibility exists, however, that disturbances in the mechanisms of histamine inactivation might occur, making histamine from the digestive tract toxic. It was therefore considered of interest to examine the histamine inactivating ability of the tissues interposed between the digestive tract and the systemic circulation. As the histamine first passes into the epithelium of the gastro-intestinal wall, it seemed natural at first to examine this tissue. Experiments were also undertaken to study the nature of the inactivation and further, in which layer the inactivation of histamine takes place in the wall of the digestive tract.

The histamine content of the tissue itself had to be taken into consideration when the histamine inactivating capacity was calculated. Since sparse information was available in the literature as to the histamine content in tissues of sheep, the figures obtained for histamine content in the tissues of the digestive tract of sheep are included in this report.

\section{METHODS}

Tissues from sheep were obtained at a slaughterhouse. The animals. were of both sexes and the age judged to vary from about 9 months to about 7 years. Slaughter was done by applying electrical stunning followed by severing the blood vessels of the neck. Sections of the whole wall of rumen, reticulum, omasum, abomasum and segments of about $30 \mathrm{~cm}$ of duodenum, jejunum and ileum were cleaned with Ringer's solution and transferred to thermos flasks containing partly frozen Ringer's solution. The samples of the abomasal wall were taken from the fundus. Tissues characterized as samples of the duodenal, jejunal and ileal wall were taken from between sphincter pylori and the entrance of the bile-duct, about $5 \mathrm{~m}$ caudally to the entrance of the bile-duct, and about $1 / 2 \mathrm{~m}$ cranially to the ileo-caecal junction, respectively. In a few experiments approximately 25 min. elapsed between killing and transfer of tissues to the Ringer's solution, but in most experiments this was accomplished within $10 \mathrm{~min}$.

\section{Preparation of the tissues}

The wall of the digestive tract comprises predominantly two different types of tissue, the epithelium and the muscle. The histamine 
inactivating capacity of each was in most experiments studied separately. Peeling off the mucosa from the rest of the wall was easily accomplished, especially with the fore-stomachs. No histological examinations were carried out and preparations termed as mucosa or epithelium certainly contained some connective tissue in addition to epithelial cells. A part of each tissue was gently blotted on filter paper, and aliquots weighed (usually $1 \mathrm{~g}$ ). In some experiments the epithelium was incubated as undamaged as possible (termed "intact" epithelium). In others the epithelium ( $1 \mathrm{~g})$ was minced in a glass homogenizer (Griffith's tube, Baird \& Tatlock, Ltd., London). Preparations of the muscle-layer and the whole wall were obtained by cutting the tissues in thin sections with scissors. During the preparation of both the mucosa and the muscle, stress was laid on keeping the temperature of the tissues low.

\section{Determination of the content of histamine in the tissues}

Samples of the different tissues were heated at $80^{\circ} \mathrm{C}$ for about 3 min., whereupon the histamine content was determined by two different methods:

1. One $g$ of the tissue was disintegrated in the glass homogenizer. The homogenate was diluted with Tyrode's solution (the amounts of Tyrode depending on the expected quantity of histamine), and the histamine content assayed on isolated atropinized $(0.05 \mathrm{mg}$ atropine/1) guineapig ileum.

2. One $\mathrm{g}$ of tissue was boiled for $5 \mathrm{hrs}$. with $10 \mathrm{ml}$ of $10 \% \mathrm{HCl}$ according to Best \& McHenry (1930). By this procedure the tissue was completely disintegrated. After centrifuging the hydrolyzates at $3000 \times \mathrm{g}$ for 5 min., the supernatants were evaporated to complete dryness ex vacuo. The residues were dissolved in Tyrode's solution and the histamine content of the neutralized extracts determined. Preliminary experiments revealed that the values obtained by the two methods agreed well when the histamine content of tissues with low texture was determined. When the histamine content of tissues with high texture (epithelium of the fore-stomachs, muscle preparations) were examined, simple glass homogenization gave somewhat lower and more variable values than disintegration by boiling with $\mathrm{HCl}$. Accordingly, glass homogenization was used for the abomasal and intestinal mucosa, whereas disintegration with $\mathrm{HCl}$ was used for the other types of tissue examined.

\section{Determination of histamine inactivation}

Two times $2 \mathrm{ml}$ of Ringer's solution, preheated to $37^{\circ} \mathrm{C}$, were used for transferring each aliquot of tissue homogenate (corresponding to $1 \mathrm{~g}$ ) quantitatively to Warburg vessels containing $0.1 \mathrm{ml}$ of a Ringer's solution with variable amounts of histamine. Aliquots of the muscular layer, the whole wall, or "intact" epithelium were transferred to Warburg vessels, containing $4 \mathrm{ml}$ of Ringer's solution $\left(37^{\circ} \mathrm{C}\right)$ with 
histamine. Aminoguanidine was occasionally added to the incubation fluid simultaneously with the substrate. The Warburg vessels were gassed for about $1 \mathrm{~min}$. with $95 \% \mathrm{O}_{2}-5 \% \mathrm{CO}_{2}$. The interval between slaughtering and incubation never exceeded $2 \mathrm{hrs}$.

After incubation at $37^{\circ} \mathrm{C}$ for $2 \mathrm{hrs}$, inactivation of histamine was terminated by rapid heating of the incubation mixture to $80^{\circ} \mathrm{C}$. The tissues were then disintegrated either by mincing in a glass homogenizer or by boiling with $10 \mathrm{ml}$ of $10 \% \mathrm{HCl}$, depending on which procedure gave the highest yields of histamine in each specific tissue (see above). In some experiments the remaining histamine in the tissues and the incubation fluid was determined separately, whereas in others only the total amount of histamine left was determined. In experiments where aminoguanidine was added to the incubation medium it was occasionally controlled that this substance did not interfere with the biological determination of histamine.

Analyses of histamine standard solutions (11 duplicates, 5.2-8.5 $\mu \mathrm{g}$ histamine diphosphate/ml) had a standard deviation of \pm 0.35 , corresponding to a coefficient of variation of 4.7. Since the histamine inactivation was determined by difference, low accuracy would be obtained in case of low percentage inactivation. Thus an inactivation of $30 \%$ would be determined with a coefficient of variation of about 11 , whereas the corresponding figure for $70 \%$ inactivation would be about 2 . The coefficients of variation actually obtained when histamine inactivation was determined were, however, larger than when standard solutions of histamine were assayed. The histamine inactivating capacity of minced mucosa of the small intestines (usually $50-70 \%$ inactivation) was for instance determined with a coefficient of variation of 6.4 .

In some experiments the decrease in substrate concentration during the incubation period was too small to be accurately determined. The main reason for this was that some tissues contained high concentrations of preformed histamine, but inactivated histamine at a slow rate. If the decrease in substrate concentration should be of an order that could be accurately determined, it would necessitate incubation periods of undesired length.

\section{Determination of optimal substrate concentration}

In preliminary experiments it was found that when homogenates of ileal mucosa ( $1 \mathrm{~g}$ ) was incubated for 2 hrs. with $4 \mathrm{ml}$ of Ringer's solution, maximal histamine inactivation was obtained when the initial amounts of histamine were $300 \mu \mathrm{g}$ (Fig. 1). When homogenates of liver or kidney tissue were incubated for $2 \mathrm{hrs}$. with optimal substrate concentrations, the histamine inactivation was linearly related to the incubation time (Sjaastad, $1967 \mathrm{~d}$, e). It was therefore assumed that the inactivation of histamine was linearly related to time also in experiments with intestinal mucosa. The figures obtained for histamine inactivation in these tissues are thus believed to represent the maximal rate of inactivation. 


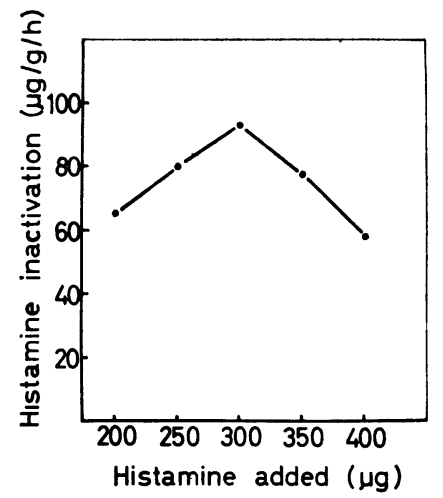

$\mathrm{Fig} \mathrm{u} \mathrm{r}$ e 1. Inactivation of histamine in homogenates of ileal mucosa at different substrate concentrations. All values are the mean of 4 experiments. Incubation period: $2 \mathrm{hrs}$. Amount of tissue: $1 \mathrm{~g}$.

In tissues where the histamine inactivation was slow, the optimal substrate concentration was not determined. It is therefore possible that the figures given for histamine inactivation do not represent the inactivating capacities of these tissues.

The values for histamine inactivation are expressed as $\mu \mathrm{g}$ of histamine diphosphate inactivated per $\mathrm{g}$ wet weight of tissue per hr., and represent the mean of duplicate experiments. The variability of histamine values is consistently given as standard deviations. All histamine values refer to histamine diphosphate.

\section{MATERIALS}

Histamine diphosphate was obtained from Nutritional Biochemicals Corp., Cleveland, Ohio.

Aminoguanidine bicarbonate was bought from L. Light \& Co., Ltd., Colnbrook.

\section{RESULTS}

The concentration of histamine in tissues of the wall of the digestive tract

The concentration of histamine in the fore-stomachs was lower than in the rest of the digestive tract examined (Table 1). In the mucosa, the concentration was significantly lower in the terminal ileum than in both jejunum $(P<0.05$, Student's t-test) and duodenum $(\mathrm{P}<0.01)$. The difference between duodenal and jejunal mucosa was not statistically significant $(P>0.05)$. In the fore-stomachs histamine was fairly evenly distributed between the epithelium and the muscle layer whereas in the abomasum 
and the small intestines most of the histamine resided in the mucosa. The range in histamine concentration was wide in all tissues (Table 1).

Table 1. Histamine content in tissues of the wall of the digestive tract in sheep.

\begin{tabular}{lcc}
\hline Tissue & $\begin{array}{c}\text { Number of } \\
\text { animals }\end{array}$ & $\begin{array}{c}\text { Histamine concentration } \\
\mu \mathrm{g} / \mathrm{g} \text { wet weight (mean } \pm \mathrm{s})\end{array}$ \\
\hline Rumen epithelium & 11 & $7.4 \pm 3.6$ \\
Rumen muscle & 11 & $6.5 \pm 4.2$ \\
Reticulum epithelium & 4 & $7.8 \pm 2.2$ \\
Abomasum epithelium & 12 & $40.7 \pm 36.7$ \\
Abomasum muscle & 7 & $8.2 \pm 4.8$ \\
Duodenum epithelium & 8 & $121.5 \pm 90.5$ \\
Duodenum muscle & 2 & $58.0,67.1$ \\
Jejunum epithelium & 14 & $94.6 \pm 55.5$ \\
Ileum epithelium & 15 & $50.6 \pm 35.2$ \\
Ileum muscle & 3 & $39.0, \cdot 21.4,16.2$ \\
\hline
\end{tabular}

Inactivation of histamine by tissues of the digestive tract

The fore-stomachs. The inactivation of histamine by the epithelium of the different compartments of the fore-stomachs did not differ much (Table 2).

T a b l e 2. Inactivation of histamine in tissues of the fore-stomachs of sheep.

Incubation period: $2 \mathrm{hrs}$. Histamine added: $32 \mu \mathrm{g}$. Amount of tissue: $1 \mathrm{~g}$.

\begin{tabular}{lcc}
\hline Tissue & $\begin{array}{c}\text { Number of } \\
\text { animals }\end{array}$ & $\begin{array}{c}\text { Inactivation of histamine } \\
\mu \mathrm{g} / \mathrm{g} \text { wet weight of tissue/hr. } \\
\text { (mean } \pm \mathrm{s} \text { ) }\end{array}$ \\
\hline Rumen epithelium & 11 & $6.4 \pm 1.5$ \\
Rumen muscle & 7 & $11.2 \pm 2.9$ \\
Reticulum epithelium & 4 & $6.2 \pm 1.0$ \\
Omasum epithelium & 4 & $5.8 \pm 1.6$ \\
\hline
\end{tabular}

The rate of inactivation in rumen muscle was significantly higher than in rumen epithelium $(P<0.001)$.

Aminoguanidine in low concentrations is known to inhibit diamine oxidase (histaminase) completely (Schuler 1952; Waton 1956). Addition of aminoguanidine diminished the histamine inactivation both in rumen epithelium and rumen muscle. In rumen epithelium from 8 sheep the histamine inactivation in the 
presence of aminoguanidine was $3.0 \pm 1.3 \mu \mathrm{g} / \mathrm{g} / \mathrm{hr}$., compared with $6.4 \pm 1.5 \mu \mathrm{g} / \mathrm{g} / \mathrm{hr}$. (Table 2) without aminoguanidine (11 sheep). This difference was statistically significant $(P<0.001)$.

In 4 samples from the same animal the decrease in histamine in aminoguanidine-treated samples of rumen epithelium was compared with boiled controls (32 $\mu \mathrm{g}$ histamine added). The amounts of histamine left in aminoguanidine-treated samples $(29.2 \pm 0.6 \mu \mathrm{g})$ were significantly lower $(\mathrm{P}<0.05)$ than in the boiled controls $(35.8 \pm 2.8 \mu \mathrm{g})$. The amounts of histamine left in boiled samples were not significantly lower $(P>0.05)$ than the amounts of histamine at zero time $(37.3 \mu \mathrm{g})$. Since the number of observations was low, caution must, however, be exercised in the interpretation of the statistical analyses.

Abomasum. When abomasal mucosa or muscle was incubated without added histamine, only small changes in the amounts of histamine in the incubation mixtures were observed. On an average the histamine content of the mucosa (16 expts.) and the muscle (3 expts.) decreased by $16(5-25)$ and $15(4-29) \%$, respectively.

When abomasal tissue was incubated with added histamine variable results were found (Table 3 ). In all experiments the

T a b l e 3. Changes in histamine content by incubation of abomasal epithelium and muscle.

Incubation period: $2 \mathrm{hrs}$. Amount of tissue incubated: $1 \mathrm{~g}$.

\begin{tabular}{|c|c|c|c|c|c|c|}
\hline \multirow{2}{*}{$\begin{array}{l}\text { Sheep } \\
\text { no. }\end{array}$} & \multirow{2}{*}{$\begin{array}{l}\text { Preformed } \\
\text { histamine } \\
\quad(\mu \mathrm{g})\end{array}$} & \multirow{2}{*}{$\begin{array}{l}\text { Histamine } \\
\text { added } \\
(\mu \mathrm{g})\end{array}$} & \multirow{2}{*}{$\begin{array}{c}\text { Preparation } \\
\text { of } \\
\text { tissue }\end{array}$} & \multicolumn{2}{|c|}{$\begin{array}{l}\text { Histamine left after } \\
\text { incubation }(\mu \mathrm{g})\end{array}$} & \multirow{2}{*}{$\begin{array}{c}\text { Change in } \\
\text { total } \\
\text { histamine } \\
(\mu \mathrm{g})\end{array}$} \\
\hline & & & & $\begin{array}{l}\text { Tissue } \\
\text { bound }\end{array}$ & $\begin{array}{c}\text { Aqueous } \\
\text { phase }\end{array}$ & \\
\hline 1 & 8.8 & 20 & "Intact" epithelium & 30 & 3.6 & +4.8 \\
\hline 1 & 8.6 & 20 & , & 26 & 4.6 & +2.0 \\
\hline 2 & 56 & 16 & 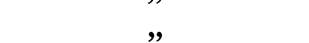 & 47 & 5.0 & -20.0 \\
\hline 2 & 57 & 16 & 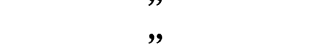 & 40 & 7.3 & -25.7 \\
\hline 3 & 12 & 200 & , & 67 & 120 & -25.0 \\
\hline 4 & 9.1 & 60 & Homogenates & \multicolumn{2}{|c|}{$50^{\star}$} & -19.1 \\
\hline 5 & 89 & 60 & , & \multicolumn{2}{|c|}{$134^{\star}$} & -14.0 \\
\hline 5 & 89 & 60 & "Intact" epithelium & \multicolumn{2}{|c|}{$135^{\star}$} & -16.0 \\
\hline 1 & 4.8 & 20 & Abomasal muscle & 11 & 2.1 & -11.7 \\
\hline 1 & 5.0 & 20 & 川 & 13 & 1.4 & -10.6 \\
\hline 2 & 5.1 & 16 & 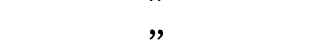 & 4.4 & 3.0 & -13.7 \\
\hline
\end{tabular}

* Tissue bound + Aqueous phase. 
histamine in the incubation fluid decreased during the incubation (Table 3 ). In some experiments the histamine content of the tissue also decreased, whereas an accumulation of histamine in the tissue was observed in others (Table 3 , sheep no. 1 , both abomasal mucosa and muscle).

Small intestines. When "intact" ileal epithelium was incubated without added histamine the changes in the histamine content were small and without any special trend (Table 4).

T a b l e 4. Changes in preformed histamine by incubation of ileal mucosa at $37^{\circ} \mathrm{C}$. Incubation period: $2 \mathrm{hrs}$. Amount of tissue: $1 \mathrm{~g}$.

\begin{tabular}{|c|c|c|c|c|}
\hline \multirow{2}{*}{$\begin{array}{l}\text { Shcep } \\
\text { no. }\end{array}$} & \multirow{2}{*}{$\begin{array}{l}\text { Preparation } \\
\text { of tissue }\end{array}$} & \multirow{2}{*}{$\begin{array}{l}\text { Initial content } \\
\text { of histamine }(\mu \mathrm{g})\end{array}$} & \multicolumn{2}{|c|}{$\begin{array}{c}\text { Histamine left after incubation } \\
(\mu \mathrm{g})\end{array}$} \\
\hline & & & $\begin{array}{l}\text { Tissue } \\
\text { bound }\end{array}$ & $\begin{array}{l}\text { Aqueous } \\
\text { phase }\end{array}$ \\
\hline 1 & "Intact" tissue & 27 & & \\
\hline 2 & " & 158 & 125 & 0 \\
\hline 2 & , & 147 & 125 & 0 \\
\hline 3 & $\eta$ & 43 & 45 & 2.0 \\
\hline 4 & 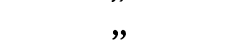 & 62 & 60 & 0 \\
\hline 4 & 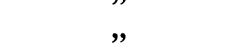 & 60 & 67 & 0 \\
\hline 5 & , & 52 & 53 & 0.5 \\
\hline 6 & ", & 28 & 23 & 0 \\
\hline 1 & Homogenate & 27 & & \\
\hline 3 & , & 48 & & \\
\hline 3 & $\eta$ & 49 & & \\
\hline 4 & 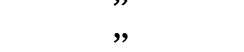 & 58 & & \\
\hline
\end{tabular}

* Tissue bound + Aqueous phase.

Similar results were found for jejunal (8 expts.) and duodenal epithelium ( 6 expts.).

When histamine (200 $\mathrm{ug})$ was added, a considerable inactivation was observed (Table 5). Homogenized samples of duodenal mucosa inactivated histamine at a rate significantly lower than both jejunal $(P<0.01)$ and ileal mucosa $(P<0.001)$. The difference between the rate of inactivation in homogenized samples of the mucosa from jejunum and ileum was not statistically significant $(\mathrm{P}>0.05)$.

With mucosa from ileum the rate of histamine inactivation was significantly higher in homogenates than in "intact" epithelium $(P<0.01)$. In jejunum the difference between the rates of inactivation in homogenates and "intact" mucosa was not statistically significant if all values obtained were used for the 
Table 5. Inactivation of histamine in the mucosa of the small intestines. The initial amounts of histamine were $200 \mu \mathrm{g}$ in experiments with duodenal tissue, otherwise $300 \mu \mathrm{g}$. Incubation period: $2 \mathrm{hrs}$. Amount of tissue: $1 \mathrm{~g}$.

\begin{tabular}{|c|c|c|c|c|c|}
\hline \multicolumn{6}{|c|}{$\begin{array}{c}\text { Inactivation of histamine } \\
(\mu \mathrm{g} / \mathrm{g} \text { wet weight of tissue } / \mathrm{hr} .)\end{array}$} \\
\hline \multicolumn{2}{|c|}{ Duodenum } & \multicolumn{2}{|c|}{ Jejunum } & \multicolumn{2}{|c|}{ Ileum } \\
\hline Homogenates & $\begin{array}{c}\text { Intact } \\
\text { epithelium }\end{array}$ & Homogenates & $\begin{array}{c}\text { Intact } \\
\text { epithelium }\end{array}$ & Homogenates & $\begin{array}{c}\text { Intact } \\
\text { ephithelium }\end{array}$ \\
\hline $\mathrm{n}=6$ & $\mathbf{n}=\mathbf{3}$ & $\mathrm{n}=10$ & $n=6$ & $\mathrm{n}=14$ & $\mathrm{n}=10$ \\
\hline $32.0 \pm 15.1$ & $23.5 \pm 15.7$ & $85.8 \pm 29.7$ & $57.8 \pm 16.7$ & $103.1 \pm 18.9$ & $72.8 \pm 18.9$ \\
\hline
\end{tabular}

statistical analysis $(0.05<\mathrm{P}<0.1)$. As the individual differences in the rate of histamine inactivation were large, it seemed, however, to be a more logical approach only to use the values from sheep in which both homogenates and "intact" epithelium had been examined. The inactivating capacities of homogenates and “intact" epithelium (5 animals) were then $104.2 \pm 28.7 \mu \mathrm{g} / \mathrm{g} / \mathrm{hr}$. and $62.8 \pm 13.4 \mu \mathrm{g} / \mathrm{g} / \mathrm{hr}$., respectively. This difference was statistically significant $(\mathrm{P}<0.05)$. When histamine $(30 \mu \mathrm{g})$ was

Table 6. Effect of aminoguanidine $\left(10^{-4} \mathrm{M}\right)$ on the inactivation of histamine in jejunal and ileal mucosa.

Amount of tissue: $1 \mathrm{~g}$. Histamine added: $200 \mu \mathrm{g}$.

\begin{tabular}{|c|c|c|c|c|c|}
\hline \multirow{2}{*}{$\begin{array}{l}\text { Sheep } \\
\text { no. }\end{array}$} & \multirow{2}{*}{ Tissue } & & \multirow{2}{*}{$\begin{array}{c}\text { Total histamine } \\
\text { before incubation } \\
(\mu \mathrm{g})\end{array}$} & \multicolumn{2}{|c|}{$\begin{array}{c}\text { Histamine left after } \\
\text { incubation } \\
(\mu \mathrm{g})\end{array}$} \\
\hline & & & & $\begin{array}{l}\text { Without } \\
\text { inhibitor }\end{array}$ & $\begin{array}{l}\text { With } \\
\text { inhibitor }\end{array}$ \\
\hline 1 & Ileum & $(\mathrm{H})^{*}$ & 261 & 59 & 260 \\
\hline 1 & " & $(I)^{\star}$ & 261 & 190 & 293 \\
\hline 2 & , & $(\mathrm{H})$ & 228 & 27 & 189 \\
\hline 3 & 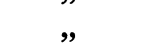 & $(\mathrm{H})$ & 244 & 33 & 256 \\
\hline 4 & $"$ & $(\mathrm{H})$ & 255 & 95 & 227 \\
\hline 5 & , & $(\mathrm{H})$ & 222 & 75 & 214 \\
\hline 1 & Jejunum & $(\mathrm{H})$ & 300 & 187 & 340 \\
\hline 2 & , & $(\mathrm{H})$ & 251 & 144 & 192 \\
\hline 6 & , & (H) & 265 & 43 & 287 \\
\hline 6 & , & (I) & 265 & 145 & 269 \\
\hline 3 & " & $(\mathrm{H})$ & 285 & 40 & 260 \\
\hline 3 & $"$ & (I) & 285 & 131 & 253 \\
\hline
\end{tabular}

* Symbols: (H) Homogenate.

(I) "Intact" epithelium. 
added to jejunal (4 expts.) and ileal muscle (4 expts.) an inactivation of $12.2 \pm 1.9 \mu \mathrm{g} / \mathrm{g} / \mathrm{hr}$. and $10.1 \pm 2.1 \mu \mathrm{g} / \mathrm{g} / \mathrm{hr}$., respectively, was found.

Aminoguanidine abolished most of the inactivation of histamine both in homogenates and "intact" samples of mucosa (Table 6). In some experiments histamine concentration increased slightly during incubation in the presence of aminoguanidine (Table 6).

In order to avoid the influence of interindividual differences, the effect of aminoguanidine was examined in 8 samples of ileal mucosa from the same animal. Three hundred $\mu \mathrm{g}$ of histamine was added. The initial quantity of histamine (354 $\mu \mathrm{g})$ fell outside the $5 \%$ confidence interval calculated from the quantities left after incubation for $2 \mathrm{hrs}$. $(328 \pm 5.6 \mu \mathrm{g})$. In this animal the ileal mucosa thus seemed to inactivate histamine at a slow rate also in the presence of aminoguanidine.

\section{Conjugation of histamine}

In 4 experiments it was examined if conjugated histamine was formed by inactivation of histamine by ileal mucosa. The method used is described elsewhere (Sjaastad $1967 \mathrm{~d}$ ). Formation of conjugated histamine was never detected.

\section{DISCUSSION}

In most species the small intestines possess a large capacity to inactivate histamine. In rats the small intestines are the principal site for inactivation of histamine (Schayer 1953; Waton 1956), and in cats (Häger \& Kahlson 1952, Waton) and dogs (Best \& McHenry 1930, Zeller 1942, Waton) the small intestines are next to the kidneys the most potent source of histaminase.

The present study has demonstrated that added histamine is rapidly inactivated in the tissues of the small intestines also in sheep. Most of the histamine inactivating capacity of the intestinal wall resided in the epithelial layer, which is consistent with findings in cats. (Häger \& Kahlson).

In the epithelium of the fore-stomachs, on the other hand, the in vitro inactivation of histamine was slow (Table 2). Judged from the present in vitro experiments, and assuming the weight of the epithelium of the reticulo-rumen to be about $500 \mathrm{~g}$, the last mentioned tissue would inactivate approximately $3 \mathrm{mg}$ histamine per hr. The maximal rate of inactivation is probably 
somewhat higher than the in vitro experiments indicate. Nevertheless, the above mentioned data suggest that the inactivating capacity of the ruminal epithelium will be greatly exceeded if the rapid disappearance of biological active histamine from the rumen after giving histamine by mouth is mainly due to absorption of free histamine.

The abomasal mucosa did not inactivate histamine significantly (Table 3 ). This is in accordance with previous findings using the ventricle of monogastric animals (Best \& McHenry, Dworetzky \& Code 1951, Häger \& Kahlson, Waton).

In dogs Best \& McHenry and Zeller found no significant difference in the rate of inactivation of added histamine by duodenal, jejunal and caecal tissue. Furthermore, Waton did not find any obvious difference in the histamine inactivation of duodenal and ileal tissues in man and most of the common laboratory animals. Only two specimens from the different tissues were examined in each species. In the present experiments the inactivating capacity of ileum was significantly higher than that of the duodenum. In this connection it is of interest that in the cat, Mellanby (1916) found that the rate of histamine absorption from intestinal loops increased from duodenum to caecum.

Most of the inactivation of histamine in the epithelium of the digestive tract was.abolished by aminoguanidine (Table 6). This suggests that diamineoxidase (histaminase) is the principal enzyme for the in vitro inactivation of histamine in the intestinal mucosa of sheep.

Only small changes in the amount of histamine was observed when ,intact" tissue was incubated without added histamine (Table 3 and 4). Furthermore, when "intact" mucosa was incubated with added histamine, the histamine content of the tissue occasionally increased during the incubation period to an extent that could not be explained by distribution of the added histamine between tissue and incubation fluid according to a state of equilibrium. These results suggest that histamine normally present in mucosa is shielded from inactivation and that "extrinsic" histamine also is absorbed by the cell and to some extent bound in such a way that it is not readily available for enzymic degradation.

Both histamine (Copenhaver et al. 1953, Hagen 1954) and histaminase (Cotzias \& Dole 1952, Kobayashi 1957) have been assumed to be located in particles in the cell. It is likely that the 
contact between histamine and histamine inactivating systems is improved by disintegration of the tissue resulting in a higher rate of histamine inactivation in homogenates than in "intact" tissue, as found in our experiments.

Histamine methyl-transferase, on the other hand, is probably a component of the cytoplasm (Lindahl 1960). Furthermore, it has been shown that methylation of histamine takes place in liver slices of mice (Lindahl 1958a), whereas it does not occur in liver homogenates unless methyldonors are added (Lindahl $1958 \mathrm{~b})$. The higher rate of histamine inactivation in homogenates than in "intact" mucosa (Table 5) supports the assumption that methylation is of minor importance for the inactivation of histamine in vitro in intestinal mucosa of sheep. Methyldonors have not been added in the present experiments, and some damage of the tissue must necessarily have been involved in preparation of what has been termed "intact" tissue. Methylation of histamine might therefore be of relatively larger importance in undamaged cells.

The values for histamine content of the different compartments from the stomach agreed well with those obtained by Sanford (1962). In accordance with previous findings in dogs (Douglas et al. 1951) the histamine content of the intestinal wall of sheep also decreased from the duodenum to the ileum. It is of interest that the opposite situation was found as far as the capacity to inactivate histamine was concerned.

\section{REFERENCES}

Best, C. H. \& E. W. McHenry: The inactivation of histamine. J. Physiol. (Lond.) 1930, 70, 349-372.

Copenhaver, J. H., M. E. Nagler \& A. Both: Intracellular distribution of histamine. Fed. Proc. 1953, 12, 314.

Cotzias, G. C. \& V. P. Dole: The activity of histaminase in tissue. J. biol. Chem. 1952, 196, 235-242.

Dougherty, $R$. W.: Drugs effecting the motility of the rumen. Cornell Vet. 1942, 32, 269-280.

Douglas, W. W., W. Feldberg, W. D. M. Paton \& M. Schachter: Distribution of histamine and substance $P$ in the wall of the dog's digestive tract. J. Physiol. (Lond.) 1951, 115, 163-176.

Dworetzky, M. \& C.F. Code: Passage of histamine across the wall of the small bowel of guinea-pigs. Amer. J. Physiol. 1951, 166, $462-469$.

Hagen, P.: The intracellular distribution of histamine in dog's liver. Brit. J. Pharmacol. 1954, 9, 100-102. 
Häger, K. \& G. Kahlson: Distribution of histamine and histaminase in the gastro-intestinal mucosa of fed and starved cats. Acta physiol. scand. $1952,25,230-242$.

Kobayashi, Y.: A histamine metabolizing enzyme system of mouse liver. Arch. Biochem. 1957, 71, 352-357.

Lindahl, K. M.: On the biological methylation of histamine 3. Acta chem. scand. 1958a, 12, 2050—2051.

Lindahl, K. M.: Methylation of histamine by mouse liver in vitro. Acta physiol. scand. $1958 \mathrm{~b}, 43,254-261$.

Lindahl, K. M.: The histamine methylating enzyme in liver. Acta physiol. scand. 1960, 49, 114-138.

Mellanby, E.: An experimental investigation of diarrhoea and vomiting in children. Quart. J. exp. Med. 1916, 9, 165-215.

Sanford, J.: The distribution of histamine in the sheep stomach. Res. vet. Sci. $1962,3,382-389$.

Schayer, $R$. W.: Studies on histamine-metabolizing enzymes in intact animals. J. biol. Chem. 1953, 203, 787-793.

Schuler, W.: Zur Hemmung der Diaminooxydase (Histaminase). Experientia (Basel) 1952, 8, 230-232.

Sjaastad, $\emptyset$. V.: Fate of ingested histamine in sheep. I. Disappearance from the rumen. Acta vet. scand. 1967 a, 8, 157-175.

Sjaastad, $\emptyset$. V.: Fate of ingested histamine in sheep. II. Faecal and urinary excretion. Acta vet. scand. $1967 \mathrm{~b}, 8,176-183$.

Sjaastad, $\emptyset$. V.: Determination and occurrence of histamine in rumen liquor of sheep. Acta vet. scand. $1967 \mathrm{c}, 8,50-70$.

Sjaastad, $\emptyset$. V.: The in vitro catabolism of histamine by sheep liver tissue. Acta physiol. scand. $1967 \mathrm{~d}$. In press.

Sjaastad, $\emptyset$. V.: The in vitro catabolism of histamine by kidney tissue of sheep. Acta pharmacol. (Kbh.) 1967 e. In press.

Sperber, I., S. Hydén \& J. Ekman: The use of polyethylene glycol as a reference substance in the study of ruminant digestion. Ann. roy. agric. Coll. Sweden 1953, 20, 337-344.

Waton, N. G.: Studies on mammalian histidine decarboxylase. Brit. J. Pharmacol. 1956, 11, 119-127.

Zeller, E. A.: Diamine oxidase. Advances in enzymology, Interscience Publ., New York 1942, 2, 93-112.

\section{SUMMARY}

A slow, but significant, histamine inactivation was found in the tissues of the fore-stomachs. The inactivation was significantly higher in rumen muscle than in rumen epithelium (11.2 and $6.4 \mu \mathrm{g}$ histamine diphosphate/g wet weight/hr., respectively). In abomasal epithelium no significant inactivation was detected. At optimal substrate concentrations homogenates of duodenal, jejunal and ileal mucosa inactivated 32.0, 85.8 and $103.1 \mu \mathrm{g} / \mathrm{g}$ wet weight of tissue/hr., respectively. Preformed histamine in the intestinal mucosa on the other hand, decreased from duodenum to ileum. In ileal and jejunal mucosa the inactivation in homogenates was significantly larger than in epithelium left as intact as possible. 
Most of the histamine inactivation by the epithelium in the digestive tract was counteracted by aminoguanidine, indicating that oxidative deamination is the major pathway for histamine inactivation in these tissues in vitro.

\section{ZUSAMMENFASSUNG \\ Der in vitro Katabolismus von Histamin in den Geweben des Ver- dauungskanales der Schafe.}

Eine langsame aber deutliche Inaktivierung von Histamin wurde in den Geweben in den Vormagen von Schafen festgestellt. Die Inaktivierung war signifikant grösser in der Pansenmuskulatur als in dem Pansenepithel, 11,2 $\mu \mathrm{g}$ und 6,4 $\mu \mathrm{g}$ Histamindiphosphat pro g feuchtem Gewicht des Gewebes pro Stunde. Im Labmagen konnte keine deutliche Inaktivierung nachgewiesen werden. Bei optimalen Substratkonzentrationen inaktivierten Homogenate vom Duodenum, Jejunum und Ileum 32,0, 85,8 bzw. 103,1 $\mu \mathrm{g}$ pro $\mathrm{g}$ feuchtem Gewicht des Gewebes pro Stunde. Preformiertes Histamin in der intestinalen Mucosa nahm dagegen vom Duodenum zum Ileum ab. Mit Epithel vom Jejunum und Ileum war die Histamininaktivierung signifikant höher in Homogenaten als in Präparaten, wo das Epithel so intakt wie möglich bewahrt wurde. Die Inaktivierung in der Muskelschicht des Dünndarmes war gering im Vergleich zum Epithel.

Der grösste Teil der Histamininaktivierung im Dünndarmepithel wurde durch Aminoguanidin behoben. Dieses lässt vermuten, dass eine oxydative Deaminierung der wichtigste Weg des Histaminabbaues in diesen Geweben in vitro ist.

\section{SAMMENDRAG}

Inaktivering av histamin in vitro i vev fra fordøyelseskanalen hos sau.

En langsom, men tydelig inaktivering av histamin ble funnet $i$ vevene $i$ formagene hos sau. Inaktiveringen var signifikant høyere i rumen-muskulaturen enn i rumen-epitelet, henholdsvis 11,2 $\mu \mathrm{g}$ og $6,4 \mu \mathrm{g}$ histamindifosfat/g våt vekt av vev/time. I løpeepitel kunne det ikke demonstreres noen tydelig inaktivering. Ved optimale substratkonsentrasjoner inaktiverte homogenater av duodenum, jejunum og ileum henholdsvis $32,0,85,8 \mathrm{og} 103,1 \mu \mathrm{g} / \mathrm{g}$ våt vekt av vev/time. Preformert histamin $i$ intestinal mucosa avtok derimot fra duodenum til ileum. Med epitel fra jejunum og ileum var histamininaktiveringen signifikant høyere i homogenater enn i preparater hvor epitelet ble beholdt så intakt som mulig. Inaktiveringen i muskellaget i tynntarmen var lav sammenlignet med epitelet.

Mesteparten av histaminaktiveringen i tynntarmsepitelet ble opphevet av aminoguanidin, noe som tyder på at oksydativ deaminering er den viktigste nedbrytningsbane for histamin $i$ disse vev in vitro. 